University of Nebraska - Lincoln

DigitalCommons@University of Nebraska - Lincoln

Faculty Papers and Publications in Animal

Science

Animal Science Department

January 1991

\title{
OVULATION RATE AND TWINNING RATE IN CATTLE: HERITABILITIES AND GENETIC CORRELATION
}

\author{
L. Dale Van Vleck \\ University of Nebraska-Lincoln, dvan-vleck1@unl.edu \\ K. E. Gregory \\ Roman L. Hruska U.S. Meat Anim. Res. Center, USDA-ARS, Clay Center, NE \\ S. E. Echternkamp \\ Roman L. Hruska U.S. Meat Anim. Res. Center, USDA-ARS, Clay Center, NE
}

Follow this and additional works at: https://digitalcommons.unl.edu/animalscifacpub

Part of the Animal Sciences Commons

Van Vleck, L. Dale; Gregory, K. E.; and Echternkamp, S. E., "OVULATION RATE AND TWINNING RATE IN CATTLE: HERITABILITIES AND GENETIC CORRELATION" (1991). Faculty Papers and Publications in Animal Science. 243.

https://digitalcommons.unl.edu/animalscifacpub/243

This Article is brought to you for free and open access by the Animal Science Department at DigitalCommons@University of Nebraska - Lincoln. It has been accepted for inclusion in Faculty Papers and Publications in Animal Science by an authorized administrator of DigitalCommons@University of Nebraska - Lincoln. 


\title{
OVULATION RATE AND TWINNING RATE IN CATTLE: HERITABILITIES AND GENETIC CORRELATION1,2
}

\author{
L. D. Van Vleck ${ }^{3}$, K. E. Gregory ${ }^{4}$ and S. E. Echtemkamp 4 \\ U.S. Department of Agriculture, Clay Center, NE 68933 \\ ABSTRACT
}

\begin{abstract}
Repeated measures of ovulation rate on puberal heifers should be an effective way to select for increased twinning rate. A reliable estimate of the genetic correlation between ovulation and twinning rates is needed to implement such selection and to predict its efficiency. Restricted maximum likelihood was used to estimate genetic correlations from subsets of data collected from the twinning project at the Roman L. Hruska U.S. Meat Animal Research Center. The animal model included numerator relationships among the animals and fixed effects of year-season of measurement, age at measurement, and birth group. Genetic correlations between averages of ovulation rates for three, four, five, six, seven, and eight estrous cycles and the occurrence of twins were, respectively, $.62, .76$, $1.00,1.00,1.00$, and .98 based on observations on 200 to 325 puberal heifers. Corresponding phenotypic correlations ranged from .06 to .26 . Genetic correlations between ovulation rate in a single estrous cycle and occurrence of twins were $.38, .98$, and .98 , respectively, for 323,430 , and 283 cows with ovulation rate measured after measurement of twinning, in the same season as measurement of twinning, and more than $1 \mathrm{yr}$ before measurement of twinning. Phenotypic correlations were $.00, .07$, and .00 . Genetic and phenotypic correlations among ovulation rates at six consecutive estrous cycles averaged, respectively, .66 and .12 for 610 heifers. Heritabilities for ovulation rates in individual cycles averaged .16. No evidence of negative environmental covariance between ovulation rates in adjacent cycles was found. These results support the approach of indirectly selecting for twinning rate by measuring ovulation rates in estrous cycles of puberal heifers.
\end{abstract}

Key Words: Selection, Genetic Correlation, Ovulation Rate, Twinning, Cattle

J. Anim. Sci. 1991. 69:3213-3219

\section{Introduction}

Initial results of the project initiated in 1981 to select for twinning in cattle at the Roman $\mathrm{L}$. Hruska U.S. Meat Animal Research Center have been documented (Echternkamp et al.,

\footnotetext{
${ }^{1}$ Published as Paper No. 9339, Joumal Ser., Nebraska Agric. Res. Div., Univ. of Nebraska, Lincoln 68583-0908.

2 Appreciation is expressed to Gordon Hays and Steve Kappes and their staff for operations support provided to this project.

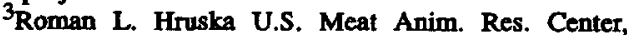
ARS, USDA, A218 Animal Sciences, Univ. of Nebraska, Lincoln 68583-0908.

${ }^{4}$ Roman L. Hruska U.S. Meat Anim. Res. Center, ARS, USDA, Clay Center, NE 68933.

Received August 30, 1990.

Accepted March 14, 1991.
}

1990; Gregory et al., 1990a,b). The small estimates of heritability $(<.10)$ for twinning rate found, which agreed with literature reviewed by Gregory et al. (1990a), as well as the long generation interval and high resource requirement to obtain measures of twinning rate led to the suggestion to use ovulation rate in puberal heifers to select indirectly for twinning rate (Echtemkamp et al., 1990). Preliminary estimates of heritability of ovulation rate in heifers and in cows were reported by Echternkamp et al. (1990). The authors also suggested that the environmental covariance between number of ovulations in adjacent estrous cycles might be negative because of the possible need for a recovery period. The covariance between ovulation rates in nonadjacent cycles might, however, be positive. 
The initial analyses for both ovulation and twinning rates were carried out with a sire and animal within sire model using Method III (Henderson, 1953) type procedures with the mixed-model package of Harvey (1977). In most analyses, repeatability was estimated to be less than heritability; this was postulated to be due to small negative environmental covariances in adjacent gestations or estrous cycles.

The objectives of this study were 1) to compare estimates of heritabilities and repeatability from the initial analyses with those using REML with an animal model when all numerator relationships among animals are considered, 2) to estimate the environmental covariances among numbers of ovulations for a series of consecutive estrous cycles, and, most importantly, 3) to estimate the genetic correlation between ovulation rate and twinning rate, which is needed to implement selection for twinning rate using ovulation rate measured in puberal heifers.

\section{Materlals and Methods}

Procedures for obtaining twinning rate, ovulation rate in cows, and ovulation rate in heifers, as well as the origin of the foundation animals, are described by Gregory et al. (1990a) and Echternkamp et al. (1990). Many of the records in this study were the same as in their reports and were used to compare methods of estimation of genetic parameters. Analyses to answer the other objectives included data from additional measures of twinning in cows and ovulation in heifers.

Programs of Meyer (1985, 1986, 1988, 1989), DFREML and REMLPK, were used for the animal model analyses. Single-trait analyses with repeated records (which allow modeling of direct genetic plus permanent environmental effects) were done with the DFREML programs. Derivative free restricted maximum likelihood (DFREML) was described by Smith and Graser (1986), Graser et al. (1987), and Meyer (1989). Multiple-trait REML was done with the REMLPK programs after modification to an animal rather than sire model and after changing the quadratics used for estimation of variance components from the rapid convergence ones (VanRaden, 1986) to the ones with slower convergence cited by Jensen and Mao (1988) and attributed to Henderson (1984). The rapid algorithm at times failed to reach convergence; this did not happen with the algorithm of Henderson (1984).

Fixed effects included in the models followed those of the earlier reports (Echternkamp et al., 1990; Gregory et al., 1990a) and are summarized briefly in footnotes to tables in the section on results.

\section{Results and Discussion}

\section{Heritability}

Estimates from DFREML with an animal model with numerator relationships are compared in Table 1 to the estimates previously obtained with a sire model with the same data sets (Echternkamp et al., 1990; Gregory et al., 1990a). Numbers of sires, females, and records are presented in Table 2. Estimates of heritability are similar for the two procedures. The DFREML procedure forces all variance components to be nonnegative. Thus, the variance of permanent environmental effects is constrained to be either zero or positive. Consequently, $h^{2}$ must be less than or equal to $r$. Whereas in all animal model analyses $\mathrm{h}^{2}$ was less than or equal to $r$, in the sire model analyses $h^{2}$ exceeded $r$ in many cases. The consistency of $h^{2}$ less than or equal to $r$ with DFREML and the animal model and the fact that all numerator relationships are used suggest the desirability of using the animal model procedure when possible if the model assumptions are met. All further analyses reported here are with REML and an animal model with numerator relationships.

Table 3 lists estimates of genetic parameters with added records. Similarity of estimates for all sets of data shown in Table 1 and in Table 3 led to the decision to use all data in subsequent analyses. Nearly twice as many heifers are included in the analyses summarized in Table 3 compared with Table 1. Cows with parturitions increased by about $20 \%$. These results suggest a slightly larger heritability for heifer ovulation rate than for twinning (10 vs $7 \%$ ) with a permanent environmental variance of approximately $2 \%$ for ovulation rate and near zero for twinning. These estimates are from a population founded from many breeds (Gregory et al., 1990a). The majority of the records, however, represent performance of later-generation animals and thus the estimates may represent the composite population. 
OVULATION AND TWINIING IN CATTLE

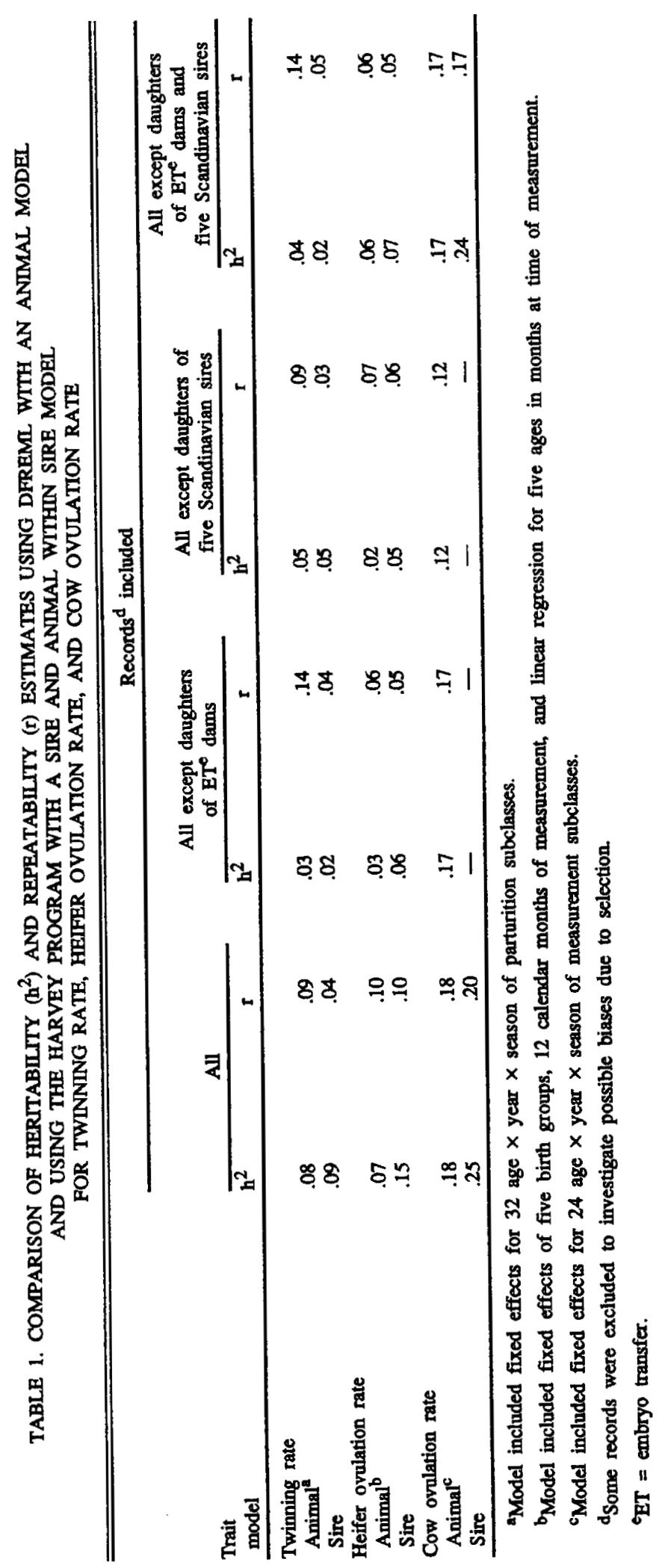




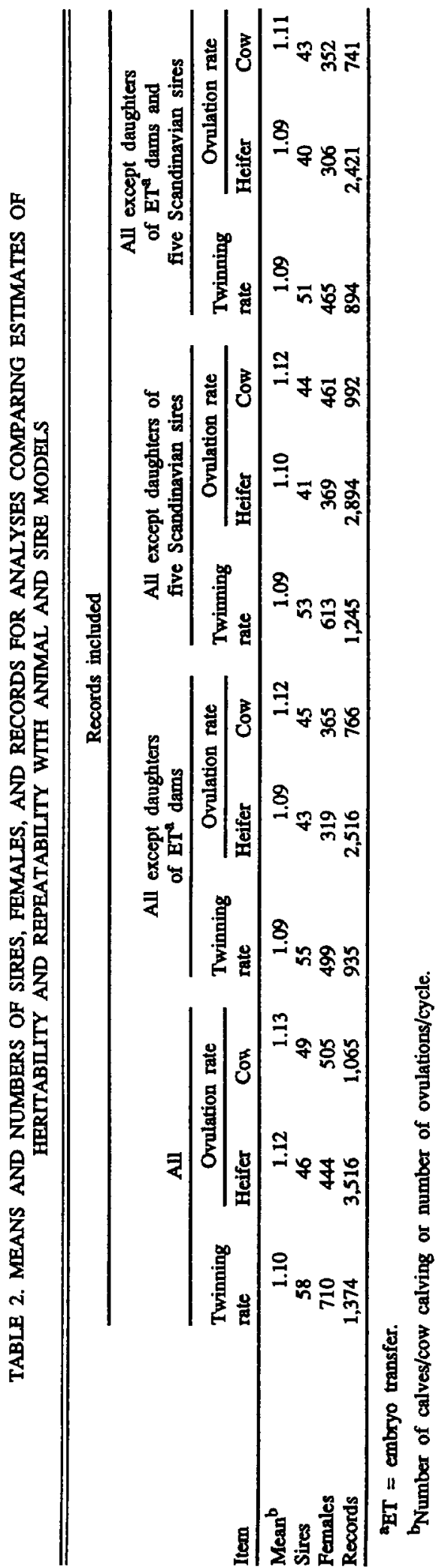

\section{Genetic Correlation}

Data available for estimating the genetic correlation between twinning rate and ovulation rate were limited. Thus, several combinations of ovulation measures and twinning measures were analyzed to extract as much information as possible from the data. The first available sets of data were those for twinning rate and ovulation rate in cows (Echternkamp et al., 1990; Gregory et al., 1990a). These records were matched in three ways, but the matches for a cow always involved only one measure of ovulation rate and one measure of twinning rate. Year-season of parturition and year-season of measurement of ovulation were the criteria for matching 1) parturition season before ovulation season, 2) parturition season the same as ovulation season (ovulation measure would have been during rebreeding after twinning was measured), and 3) parturition season more than a year after ovulation was measured. The average of estimates of genetic correlations between ovulation and twinning rates in cows shown in Table 4 suggests a high correlation as would be expected because a double ovulation usually must precede a twin birth.

One way to use ovulation rate in heifers to predict breeding value for twinning is to use the average ovulation rate from several estrous cycles, which can be observed at roughly 3-wk intervals from puberty until breeding. Consequently, averages of ovulations from three to eight consecutive estrous cycles in heifers were combined with twinning rate at the first subsequent parturition to estimate the genetic correlation. The summary of those multiple-trait REML analyses is presented in Table 5. In four of the analyses, the estimate of genetic correlation converged toward 1.00 . In all analyses, the estimate of the genetic correlation was large. The analyses were not independent, because all analyses for less than eight cycles included the 200 animals with ovulations measured in eight estrous cycles.

The question of environmental covariances among ovulations in consecutive estrous cycles was approached by considering each measurement as a separate trait with analysis by multiple-trait REML for an animal model. The analysis with eight cycles is summarized in Tables 6 and 7. A similar analysis with six cycles is not shown.

The patterns were similar for the analyses of six (677 heifers) and eight (610 of the same 
TABLE 3. ESTIMATES OF HERTTABIITY $\left(h^{2}\right)$ AND REPEATABILITY (r) BY DFREML WITH AN ANIMAL MODEL, FOR TWINNING RATE AND HEIFER OVULATION RATE

\begin{tabular}{|c|c|c|c|c|c|}
\hline \multirow[b]{2}{*}{ Trait } & \multirow[b]{2}{*}{ Mean } & \multirow[b]{2}{*}{$h^{2}$} & \multirow[b]{2}{*}{$\mathbf{r}$} & \multicolumn{2}{|c|}{ Number } \\
\hline & & & & $\begin{array}{l}\text { Animals } \\
\text { with records }\end{array}$ & Records \\
\hline $\begin{array}{l}\text { Heifer ovulation rate } \\
\text { Heifer ovulation rate }\end{array}$ & $\begin{array}{l}1.133 \\
1.135\end{array}$ & $\begin{array}{l}.098 \\
.099\end{array}$ & $\begin{array}{l}.116 \\
.118\end{array}$ & $\begin{array}{l}840 \\
779\end{array}$ & $\begin{array}{l}6,912 \\
6,685\end{array}$ \\
\hline Twinning rate $\mathrm{d}$ & 1.110 & .072 & .072 & 851 & 1,929 \\
\hline
\end{tabular}

aAll heifers with ovulation rates measured.

b Model included birth-year-season group, calendar month measured, age in months at measurement $(\leq 11,12$ to 13 , 14 to 15,16 to $17, \geq 18$ ).

${ }^{c}$ All heifers except birth group associated with embryo transfer dams.

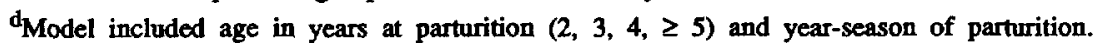

heifers) consecutive estrous cycles. The average heritability estimate was larger for the single measurements than for the analysis using the repeated measurement model: .17 with six cycles and .16 with eight cycles, compared with .10 in Table 3 . The probable cause is that the average estimated genetic correlation for the analysis of six cycles is .66 and for eight cycles (Table 6) is .63. The repeated records model assumes a genetic correlation of unity between all pairs of measurements of ovulation. The biological reason for a genetic correlation different from unity is not clear, because for ovulations measured six or eight times within 18 to 24 wk there is no obvious way to describe the measurement times other than as random, although chronological, estrous events. The mean ovulation rate does increase slightly in later cycles (Echternkamp et al., 1990). Similarly, the macroenvironment cannot have changed much from one cycle to the next. Perhaps the binomial nature of measurements should be studied to determine whether that is the cause when the measurements of single, double, or triple ovulations are subject to error. A simulation study is planned to examine this question.

The phenotypic correlations averaged .12 for both the analyses of six and eight estrous cycles and agree closely with the repeatability estimates of .116 and .118 in Table 3 .

The environmental covariances presented in Table 7 do not show any obvious pattern of negative covariances between adjacent measurements or positive covariances between measurements separated by greater lengths of time. The average environmental covariances are .0014 for the analysis of six cycles and .0021 in Table 7 , which are only 1 to $2 \%$ of the average environmental variances of .0992 and .1034. The covariances for adjacent measurements are .0022 and .0042 , for measurements two cycles apart are .0023 and .0056 , for measurements three cycles apart are .0041 and .0046 , and are generally slightly negative for measurements four or more cycles apart.

TABLE 4. ESTIMATES OF HERITABILITIES AND GENETIC $\left(r_{g}\right)$ AND PHENOTYPIC $\left(r_{p}\right)$ CORRELATIONS USING MULTIPLE-TRAIT RESTRICTED MAXIMUM LIKELIHOOD WITH AN ANIMAL MODEL ${ }^{a}$ FOR OVULATION RATE AND TWINNING RATE MATCHED IN DIFFERENT WAYS

\begin{tabular}{|c|c|c|c|c|c|}
\hline \multirow{2}{*}{$\begin{array}{l}\text { Parturition season (T) vs } \\
\text { Ovulation season }(O)\end{array}$} & \multirow{2}{*}{$\begin{array}{l}\text { No. of } \\
\text { matches }\end{array}$} & \multicolumn{2}{|c|}{ Heritability } & \multirow[b]{2}{*}{$\mathbf{r}_{\mathrm{g}}$} & \multirow[b]{2}{*}{$\mathrm{r}_{\mathrm{p}}$} \\
\hline & & Ovulation & Twinning & & \\
\hline $\begin{array}{l}\mathbf{T}<0 \\
\mathrm{~T}=0 \\
\mathbf{T}>0^{b}\end{array}$ & $\begin{array}{l}323 \\
430 \\
283\end{array}$ & $\begin{array}{l}.18 \\
.13 \\
.06\end{array}$ & $\begin{array}{l}.29 \\
.02 \\
.15\end{array}$ & $\begin{array}{l}.38 \\
.98 \\
.98\end{array}$ & $\begin{array}{l}.00 \\
.07 \\
.00\end{array}$ \\
\hline
\end{tabular}

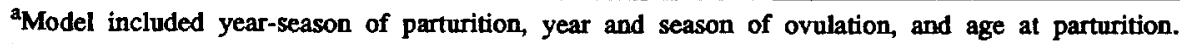

beason of parturition more than 1 yr later than season ovulation rate measured to avoid observed ovulation measure resulting in observed parturition. 
TABLE 5. ESTIMATES OF HERITABIITIES AND GENETIC $\left(r_{g}\right)$ AND PHENOTYPIC $\left(r_{p}\right)$ CORRELATIONS FOR AVERAGE OF OVULATION RATE AT $n$ ESTROUS CYCLES OP HEIFERS AND TWINNING RATE AT FIRST SUBSEOUENT CALVING USING MULTIPLE-TRAIT RESTRICTED MAXIMUM LIKELIHOOD WTTH AN ANIMAL MODEL

\begin{tabular}{|c|c|c|c|c|c|}
\hline \multirow[b]{2}{*}{ n } & \multirow{2}{*}{$\begin{array}{l}\begin{array}{l}\text { No. of } \\
\text { matches }\end{array} \\
\end{array}$} & \multicolumn{2}{|c|}{ Heritability } & \multirow[b]{2}{*}{$r_{g}$} & \multirow[b]{2}{*}{$\mathbf{r}_{p}$} \\
\hline & & Ovulation & Twinning & & \\
\hline 3 & 325 & .16 & .09 & .62 & .06 \\
\hline 4 & 288 & .24 & .15 & .76 & .08 \\
\hline 5 & 243 & .22 & .05 & 1.00 & .13 \\
\hline 6 & 229 & .24 & .06 & 1.00 & .19 \\
\hline 7 & 219 & .21 & .04 & 1.00 & .22 \\
\hline 8 & 200 & .27 & .002 & .98 & .26 \\
\hline
\end{tabular}

${ }^{a}$ Model included birth group, calendar month ovulation rate first measured, age in months when ovulation rate first measured $(\leq 11,12$ to 13,14 to 15,16 to $17, \geq 18)$, and age in years at parturition $(2, \geq 3)$.

\section{Conclusions}

Heritability estimates were similar using the animal model with DFREML and using the sire and animal within sire model with Method III estimation. Estimates of repeatability were more in agreement with the repeated records model with the animal model than with the sire and animal within sire model, for which several negative estimates of permanent environmental variance were found. The animal model also incorporates all numerator relationships and thus seems preferable to the sire model when computer capacity is sufficient.

Environmental covariances among ovulation rates for consecutive estrous cycles do not suggest a pattem of negative covariances for measurements in adjacent cycles. The environmental covariances are small relative to environmental variances.

Genetic correlations among ovulation measurements in consecutive estrous cycles seem to be much less than unity, about .63 to .66 . The genetic correlation between ovulation rate and twinning rate seems to be large, approximately .80 based on data from cows and .90 based on data from puberal heifers.

\section{Implications}

The results shown in this paper confirm the idea that ovulation rate in puberal heifers could be used effectively to select for breeding value for twinning rate. A large genetic correlation of .80 to .90 found here is the key part to confirming the theoretical advantage of indirect selection for twinning rate based on ovulation rate. Another important factor is that heritability for ovulation rate is at least as large as that for twinning rate. Two other factors are obvious. Several measurements of ovulation rate can be made in puberal heifers before breeding, which increases markedly the effec-

TABLE 6. ESTIMATES ${ }^{a}$ OF HERTTABILITIES (DIAGONAL) AND GENETIC (BELOW DIAGONAL) AND

PHENOTYPIC (ABOVE DIAGONAL) CORRELATIONS FROM OVULATION RATES OF 610 HEIFERS MEASURED IN FIRST EIGHT ESTROUS CYCLES USING MULTIPLE-TRAIT RESTRICTED MAXIMUM LIKELIHOOD WITH AN ANIMAL MODEL ${ }^{b}$

\begin{tabular}{|c|c|c|c|c|c|c|c|c|}
\hline Cycle & 1 & 2 & 3 & 4 & 5 & 6 & 7 & 8 \\
\hline 1 & .18 & .11 & .13 & .16 & .09 & .11 & .13 & .14 \\
\hline 2 & $\overline{96}$ & .20 & .21 & .12 & .05 & .05 & .07 & -.02 \\
\hline 3 & .32 & .50 & .17 & .16 & .08 & .13 & .11 & -.05 \\
\hline 4 & .38 & .38 & .76 & .09 & .14 & .13 & .15 & .06 \\
\hline 5 & .49 & .33 & .31 & $\overline{\mathbf{8 3}}$ & .20 & .13 & .15 & .08 \\
\hline 6 & .79 & .68 & .31 & .64 &.$\overline{85}$ & .22 & .24 & .18 \\
\hline 7 & .80 & .75 & .60 & .84 & .80 & $\overline{.79}$ & .14 & .13 \\
\hline 8 & .86 & .68 & .08 & .49 & .78 & .88 & .82 & .10 \\
\hline
\end{tabular}

astandard errors ranged from .03 to .08 for heritability, from .03 to .30 for genetic, and from .02 to .04 for phenotypic correlations.

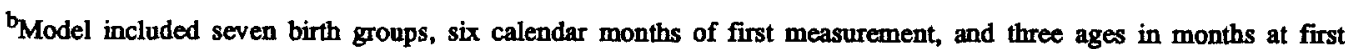
measurement. 
TABLE 7. ESTIMATES OP ENVIRONMENTAL VARIANCES (DIAGONALS) AND COVARIANCES FROM OVULATION RATES MEASURED IN FIRST EIGHT ESTROUS CYCLES OF 610 HEIFERS USING MULTIPLE-TRAIT RESTRICTED MAXTMUM LIKELIHOOD WITH AN ANIMAL MODEL

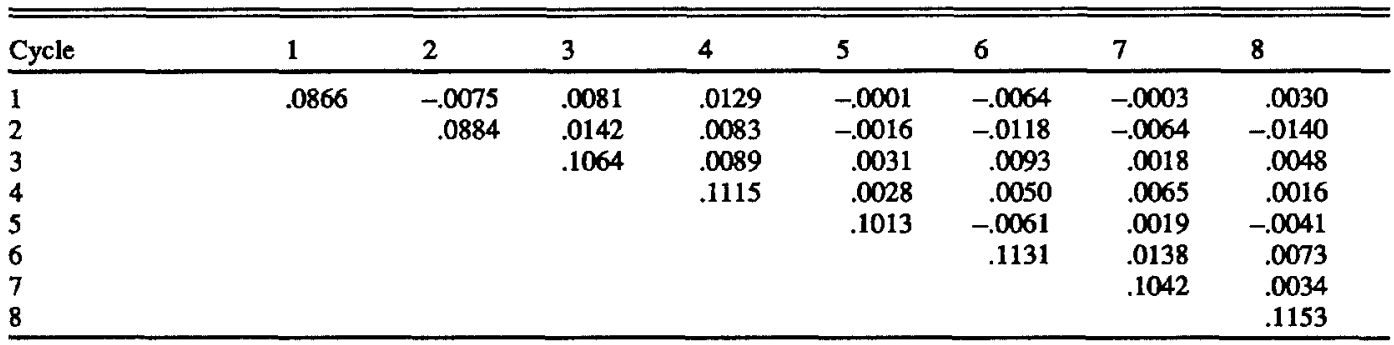

tiveness of indirect selection. The measures of ovulation rate are also available a year earlier than a single measure of twinning rate at first parturition, when twinning frequency is less than at older ages.

\section{Literature Clted}

Echternkamp, S. E., K. E. Gregory, G. E. Dickerson, L. V. Cundiff, R. M. Koch and L. D. Van Vleck 1990. Twinning in caftle: $\Pi$. Genetic and environmental effects on ovulation rate in puberal heifers and postpartum cows and the effects of ovulation rate on embryonic survival. J. Anim. Sci. 68:1877.

Graser, H.-U., S. P. Smith and B. Tier. 1987. A derivativefree approach for estimating variance components in animal models by restricted maximum likelihood. J. Anim. Sci. 64:1362.

Gregory, K. E., S. E. Echternkamp, G. E. Dickerson, L. V. Cundiff, R. M. Koch and L. D. Van Vleck. 1990a. Twinning in cattle: I. Foundation animals and genetic and environmental effects on twinning rate. J. Anim. Sci. 68:1867.

Gregory, K. E., S. E. Echternkamp, G. E. Dickerson, L. V. Cundiff, R. M. Koch and L. D. Van Vleck. 1990b. Twinning in cattle: III. Effects of twinning on dystocia, reproductive traits, calf survival, calf growth and cow productivity. J. Anim. Sci. 68:3133.

Harvey, W. R. 1977. User's guide for LSML, 76. Mixed model least-squares and maximum likelihood computer program. Ohio State Univ., Columbus (Mimeo).

Henderson, C. R. 1953. Estimation of variance and covariance components. Biometrics 9:226.

Henderson, C. R. 1984. Applications of Linear Models in Animal Breeding. University of Guelph, ON, Canada.

Jensen, J. and I. L. Mao. 1988. Transformation algorithms in analysis of single trait and of multitrait models with equal design matrices and one random factor per trait: A review. J. Anim. Sci. 66:2750.

Meyer, K. 1985. Maximum likelihood estimation of variance components for a multivariate mixed model with equal design matrices. Biometrics 41:153.

Meyer, K. 1986. Restricted maximum likelihood to estimate genetic parameters - in practice. Proc. 3rd World Cong. Genet. Appl. Livest. Prod., Lincoln, NE. 12:454.

Meyer, K. 1988. DFREML, a set of programs to estimate variance components under an individual animal model. J. Dairy Sci. 71(Suppl. 2):33.

Meyer, K. 1989. Restricted maximum likelihood to estimate variance components for animal models with several random effects using a derivative-free algorithm. Genet. Sel. Evol. 21:317.

Smith, S. P. and H.-U. Graser. 1986. Estimating variance components in a class of mixed models by restricted maximum likelihood. J. Dairy Sci. 69:1156.

VanRaden, P. M. 1986. Computational strategies for estimation of variance components. Ph.D. Thesis. Iowa State Univ., Ames. 